especially for the moving seal between the two fluids. The prospects of the gas turbine for automobiles and other mobile applications would be transformed if a reliable and efficient regenerator could be developed.

The problems of aerodynamic heating have been increasingly felt in high-speed aircraft and missile design, and novel means of overcoming them have been put forward, including sublimation of the surface layer of the material in the case of missiles and the use of cold fuels such as liquid hydrogen for supersonic aircraft. There are many other interesting new lines of research and development in industrial heat transfer. The dropwise condensation of vapours, which would give a useful reduction in size of power station steam condensers, has been successfully promoted chemically for copper-alloy tubes, but for stainless steel surfaces such as are used in condensing organic vapours it has not so far been possible to find a promoter which will adhere satisfactorily. The control of radiation from luminous furnace flames has been improved by research on large-scale furnaces, and, for example, the use of pitch creosote to control and improve the relation from non-luminous coke over gas flame has been successfully worked out.

In electrical engineering, the use of hydrogen, especially at elevated pressure, for cooling turboalternators, has been the biggest factor in improving the performance of machines and has made possible the increase of the output of the single unit from 200 to 350 megawatts. Liquid metals as heat carriers have received special attention from the nuclear reactor designers because of the favourable neutroncapture properties of sodium and potassium and their alloys and because of their high rates of heat transfer. It is likely that these metals will find new uses outside the nuclear field now that handling problems are being overcome.

Creative research, inventive development, inspired design and novel construction in the field of heat transfer are all needed to keep pace with the needs of modern technology.

\section{THE STUDY OF FOLK LIFE AND ITS PART IN THE DEFENCE OF CIVILIZATION}

$I^{\mathrm{N}}$

his presidential address to Section $H$ (Anthropology and Archæology), Dr. Iorwerth C. Peate points out that anthropology- the science of manis a vast field of which folk life, like archæology, is a small corner. The change of the title of Section $H$ in 1947 from "Anthropology" to "Anthropology and Archæology" is to be deprecated, since anthropology is a large enough umbrella for us all. The student of folk life is concerned with the study of every stratum in the community, and with all communities except those completely affected by a high degree of industrialization.

Folk life as a field of research has developed from the study of collections of 'bygones' in museums, and it is therefore often believed, erroneously, that it is concerned only with the post-medieval period. There is no date-line at which the study begins. Nor can it be said to end with the Industrial Revolution, for even in communities affected in part by industrialization, much evidence remains of the persistence of traditional ways of life. The traditional cultural pattern, from its early beginnings to the present day, is the basis of study.

Pioneer work in the Scandinavian countries, particularly the work of Dr. Sigura Erixon, the late Åke Campbell and the late Wilhelm von Sydow, established the standard by which most work on the subject must be judged. Certain aspects of the study may be mentioned. (a) The study of houses. Most major works on English architecture are of little use in the study of folk life, for they ignore the smaller buildings such as farmhouse and cottage. Regional studies such as Fox and Raglan's "Monmouthshire Houses" are urgently needed before any interpretative work can be carried out. (b) Similar records are required for problems such as transhumance. (c) The student of folk life should be chary of accepting uncritically such theories as those of a time-lag in fashion in areas far removed from a metropolis or of national forms of costume-theories which are based on insufficient evidence and basically unsound.

The study of folk life cannot be confined merely to visual materials. Speech and local dialects are an important part of it : vocabularies of the hearth and home, those relating to domestic animals, agriculture, festivals, religion and all social activities. The work on oral traditions carried out in England, Scotland and Wales should, Dr. Peate believes, be financed by the State. The refusal by the State to give an emergency grant to record the traditions of North and South Uist is thoroughly to be deplored.

We study the eternal task of 'building up a civilization in Nature' in all the little nations of Europe. Their traditions are the buffer between the passive barbarism of the West and the active barbarism of Eastern Europe, between two world forces which threaten to reduce the world to the level of brute sensation. The study of folk life has, therefore, a purpose beyond the mere limits of an academic discipline : not only does it contribute to the sum of scientific knowledge but also it assists in the rehabilitation of a degraded civilization.

\section{SOME ASPECTS OF CELLULAR DIFFERENTIATION}

$\mathrm{D}^{\mathrm{n}}$

R. E. N. WILLMER, president of Section I (Physiology), comments that the manner in which the cells of a highly developed organism such as man differentiate is not a problem which can ever be solved by the study of that organism alone. For example, in human embryology there comes a time when certain connective tissue cells, the fibroblasts, begin to produce collagen and form an inter-cellular fibrous matrix. The problem of the formation of these fibres was not, however, first solved for man; its solution must have already been achieved many millions of years ago when the calcareous sponges were first evolved, for they, like the majority of animals in all groups, form a ground-substance with collagen fibres.

It may therefore be more profitable to investigate the collagen-forming cells when they first appear, as, for example, in sponge embryos, than to study them only in what may be a specialized form in man. In the embryos of calcareous sponges, the fibre-forming cells originate from the flagellated cells which constitute the animal pole of the embryo. The posterior 